\title{
Pengaruh Tarif Ijarah Gadai Syariah Terhadap Mashlahah (Kepuasan) Nasabah Gadai Emas Bank Rakyat Indonesia Syariah Cabang Serang
}

\author{
Nursaman \\ Fakultas Pendidikan Vokasi, Prodi Keuangan dan Perbankan, Universitas Serang Raya (UNSERA) \\ *Email korespondensi: zeinurzaman0@ gmail.com
}

\begin{abstract}
Abstrak
Penelitian ini bertujuan untuk mengetahui bagaimana pengaruh tarif ijarah pada gadai syariah terhadap mashlahah (kepuasan) nasabah gadai emas Bank Rakyat Indonesia cabang Serang periode 2019 - 2020. Bahasan utama dalam penelitian ini adalah bagaimana pengaruh tarif ijarah pada gadai syariah secara simultan dan parsial terhadap mashlahah (kepuasan) nasabah. dimana teori dan filosofinya diambil dari Al-Qur'an, AlSunnah, dan para ahli. Metode yang digunakan dalam penelitian ini termasuk jenis assosiatif yang bertujuan mengetahui hubungan atau pengaruh antara dua variabel. Bertujuan mengetahui hubungan antarvariabel disebut korelasional. Ditinjau dari tujuan yang dicapai termasuk penelitian terapan. Ditinjau dari datanya termasuk jenis penelitian kuantitatif. Sumber datanya terdiri dari data primer, sekunder, dan populasi sampel. Operasional yang digunakan dalam penelitian ini sebagai berikut : variabelnya terdiri dari tarif ijarah sebagai variabel bebas serta mashlahah (kepuasan) nasabah sebagai variabel terikat. Selain itu data yang digunakan dalam pengujian diperoleh dari manajer keuangan bank periode 2019-2020, juga hasil wawancara dan kepustakaan. Untuk mengolah data tersebut penulis menggunakan program SPSS. Yang dilakukan uji F untuk uji simultan. Dan uji t untuk pengujian parsial, dengan tingkat signifikan 0,5 (5\%). Tarif ijarah terhadap kepuasan (maslahah) tidak berpengaruh secara signifikan, karena diatas 0,05. Penulis menyarankan agar mencari variabel lain yang mempengaruhi kepuasan (maslahah) nasabah.
\end{abstract}

Keywords : Tarif ijarah, gadai syariah, mashlahah nasabaah, gadai emas.

Saran sitasi: Nursaman. (2020). Pengaruh Tarif Ijarah Gadai Syariah Terhadap Mashlahah (Kepuasan) Nasabah Gadai Emas Bank Rakyat Indonesia Syariah Cabang Serang. Jurnal Ilmiah Ekonomi Islam, 6(03), 609-615. doi:http://dx.doi.org/10.29040/jiei.v6i3.1414

DOI: http://dx.doi.org/10.29040/jiei.v6i3.1414

\section{PENDAHULUAN}

Lembaga Keuangan Syariah (LKS) lahir dari perbankan syariah, yakni Bank Muamalah Indonesia (BMI) pada tahun 1992, pada tahun 1997 terjadi krisis keuangan berhasil lolos dari likuidasi Bank Indonesia (BI). Hal ini menjadi pemicu perkembangan Lembaga Keuangan Syariah (LKS), serta muncul LKS nonperbankan dimana pembinaan dan pengawasan dibawah depertemen keuangan, seperti pasar modal, asuransi, reksadana, serta lembaga-lembaga lainnya di seluruh Indonesia.

Salah satu produk Lembaga Keuangan Syariah di maksud adalah pembiayaan yang dalam hukum Islam kepentingan kreditur sangat diperhatikan dan di jaga. Oleh karena itu, guna menjaga kepercayaan dibolehkan meminta barang jaminan atas peinjamannya. Dalam dunia finansial barang jaminan dikenal dengan obyek jaminan (collateral) atau barang gadai (marhun) dalam gadai syariah. (Sasli Rais, 2005). Salah satu bank syariah yang ada produk gadainya adalah Bank Rakyat Indonesia Syariah cabang Serang sebagai obyek penelitian ini.

Salah satu produknya yang akan diteliti dalam penelitian ini adalah produk gadai emas faedah BRI Syariah. Menurut Antonio, gadai (rahn) dalam perbankan syariah digunakan sebagai produk pelengkap, artinya gadai (rahn) digunakan sebagai akad tambahan terhadap produk lainnya, seperti murabahah, dimana bank dapat menahan barang nasabah sebagai konsekwensi akad tersebut. Gadai (rahn) sebagai salah satu mekanisme dari perjanjian utang-piutang, khusus untuk mengatasi masalah pinjam-meminjam, baik secara individu atau kelembagaan.

Kepuasan (mashalahah) adalah bentuk keadaan, baik materi maupun non-materi, yang mampu 
meningkatkan kedudukan manusia sebagai mahluk yang paling mulia. (QS. 6:76, 14:5, 17:28, 18:21, dan 2:269). Atau mashlahah adalah merupakan suatu akibat atas terpenuhinya suatu kebutuhan atau fitrah. (P3EI, UII, 2008).

Dalam penelitian ini adalah sekitar mekanisme dan tarif ijarah pengaruhnya terhadap kepuasan (maslahah) gadai emas BRISyariah cabang Serang. Yang berlandaskan undang-undang, peraturan pemerintah atau pun fatwa-fatwa Dewan Syariah Nasional (DSN) sebagai lembaga yang diberi wewenang penuh dalam pengawasan dan penetapan aturan. Tetapi diantara gadai atau pegadaian syaraiah yang ada di sekitar Serang tidak seragam dalam mekanisme dan penentuan tarif ijarahnya, sehingga muncul asumsi di sebagian masyarakat, bahwa gadai syariah dan gadai konvensional tidak ada perbedaan, hanya yang dicari profit sebanyak-banyaknya, tanpa memperhatikan kebutuhan dan keadaan nasabah. Berdasarkan hasil baca penulis hanya ada satu fatwa Dewan Syariah Nasional MUI No : 25/DSNMUI/III/2002 yang berbunyi : "Besar biaya pemeliharaan dan penyimpanan marhun tidak boleh ditentukan berdasarkan pinjaman". Sedangkan "Besarnya pinjaman dari pegadaian syariah yang diberikan ke nasabah tergantung dari besarnya nilai barang yang akan digadaikan". (Heri Sudarsono, 2004).

Dengan banyaknya Lembaga Keuangan Syariah (LKS), baik perbankan maupun non-perbankan yang membuka gadai syariah, dalam bank ini dengan nama Gadai Faedah BRI Syariah. Diantara pegadaian syariah yang ada di kota Serang dalam menetapkan tarif ijarahnya cenderung tidak sama, sehingga bisa mengakibatkan nasabah kurang tertarik dengan produk yang mereka tawarkan, sehingga dapat menurunkan profit gadai yang ada di bank BRI Syariah cabang Serang.

Tujuan penelitian ini dimaksudkan untuk mendapatkan bukti empiris informasi tentang pengaruh tarif ijarah gadai syariah terhadap kepuasan (maslahah) nasabah gadai emas Bank Rakyat Indonesia Syariah cabang Serang.

\section{TINJAUAN PUSTAKA Definisi Tarif}

Tarif (harga) dalam bahasa Arab disebut tsaman (price), adalah suatu nilai tukar dari produk barang maupun jasa yang dinyatakan dalam satuan moneter. Harga merupakan salah satu penentu keberhasilan suatu perusahaan karena harga menentukan seberapa besar keuntungan yang diperoleh perusahaan dari penjualan produknya, baik berupa barang maupun jasa. (Kasmir, 2008). Menetapkan tarif terlalu tinggi akan menyebabkan penjualan akan menurun, namun jika tarif terlalu rendah akan mengurangi keuntungan yang dapat diperoleh organisasi perusahaan.

\section{Definisi Ijarah}

Ijarah (sewa) berasal dari bahasa Arab bentuk masdar dari kata "Aajara, Yu'jiru dan Ijaaratan" arti secara bahasa adalah menyewakan, rental, mengontrakan. (S. Askar, 2009).

Sedangkan ijarah menurut ahli ekonomi syariah: "Transaksi terhadap manfaat yang dituju, tertentu bersifat biasa dimanfaatkan, dengan suatu imbalan". (Ibrahim Bajuri, tt).

Menurut fatwa Dewan Syariah Nasional : "Akad pemindahan hak guna (manfaat) atas suatu barang atau jasa dalam waktu tertentu melalui sewa pembayaran sewa atau upah, tanpa diikuti dengan pemindahan kepemilikan barang itu sendiri”. (No : 09/DSN-MUI/IV, 2000). (Adiwarman A. Karim, 2006).

\section{Definisi Gadai}

Gadai dalam bahasa Arab disebut rahn, yaitu bentuk masdar dari kata : Rahana, Yarhanu, dan Rahnan yang artinya kekal, tinggal, menempati. (S. Askar, 2009). Arti secara bahasa rahn artinya menahan terhadap suatu barang dengan hak sehingga dapat dijadikan sebagai pembayaran dari barang tersebut. (Abdul Ghafur Anshari, 2006).

Menurut Antonio, "Gadai (rahn) adalah menahan salah satu harta milik si peminjam sebagai jaminan atas pinjaman yang diterimanya, barang yang ditahan tersebut memiliki nilai ekonomi”. (Antonio, 2000).

\section{Definisi Maslahah}

Kepuasan atau mashlahah adalah bentuk tunggal dari jamak Mashalih artinya timbangan, kata mashlahah adalah sesuatu yang yang banyak kebaikan dan manfaatnya. (Mahmud Yunus, 1990). Sedangkan lawan mashlahah adalah mafasid, yaitu sesuatu yang banyak keburukannya.

Kepuasan dalam istilah ekonomi Islam adalah bentuk keadaan, baik material maupun non-material, yang mampu meningkatkan kedudukan manusia sebagai mahluk yang paling mulia. (QS. 6:76, 14:5, 17:28, 18:21, dan 2:269). Adapun kepuasan adalah 


\section{Jurnal Ilmiah Ekonomi Islam, 6(03), 2020, 611}

suatu akibat dari terpenuhinya suatu keinginan. (P3EI, UII, 2008). Jadi walaupun demikian, terpenuhinya suatu kebutuhan juga akan memberi kepuasan terutama jika kebutuhan tersebut disadari dan diingikan.

Kepuasan atau maslahah menurut al-Syatibi : "Segala sesuatu yang menyangkut rezeki manusia, pemenuhan penghidupan manusia, dan perolehan apaapa yang dituntut oleh kualitas-kulalitas emosional dan intelektualnya, dalam pengertian yang mutlak". (Adiwarman A Karim, 2006). Dalam meningkatkan kesejahteraan umat manusia khususnya umat Islam, pertimbangan adanya mashalah haruslah mengandung empat eksioma, yaitu kesatuan (unity), keseimbangan (equllibrium), kehendak bebas (free will) dan tanggung jawab (responsibility). (Syed Nwad, 2003).

Dari keempat aksioma tersebut diatas, ada dua hal yang menjadi pijakan pokok yakni kesatuan (unity), karena kesatuan merupakan dimensi vartikal yang menunjukkan bahwa petunjuk yang benar berasal dari Allah Swt. Sedangkan yang kedua adalah keseimbangan yang menuntut terwujudnya keseimbangan masyarakat, prinsip ini menghendaki jalan yang lurus dengan menciptakan tatanan sosial yang menghindari perilaku ekstrimis.

\section{METODE PENELITIAN}

Metode penelitian pada dasarnya merupakan cara ilmiah untuk mendapatkan data dengan tujuan tertentu. (Sugiono, 2010). Dengan demikian, terdapat empat kunci yang perlu diperhatikan yaitu, cara ilmiah, data, tujuan, dan kegunaan. Tujuan utama dalam penelitian secara umum ada tiga macam : penemuan, pembuktian, dan pengembangan. (Sugiono, 2010).

Dalam penelitian ini penulis menggunakan pendekatan deskriptif kuantitatif. Metode yang digunakan dalam penelitian ini, termasuk jenis penelitian assosiatif yang bertujuan mengetahui hubungan atau pengaruh antara dua variabel atau lebih. Penelitian bertujuan mengetahui hubungan antar variabel disebut penelitian korelasional, sedangkan penelitian bertujuan mengetahui pengaruh antar variabel disebut penelitian kausal. (Sugiono, 2010). Penelitian survey digunakan untuk mendapatkan data dari tempat tertentu yang alamiah, tetapi peneliti melakukan perlakuan dalam pengumpulan data, misalnya dengan mendengar kuesioner, test, wawancara, dan sebagainya. (Sugiono, 2010).
Dilihat dari tujuan yang ingin dicapai, penelitian dilakukan termasuk jenis penelitian terapan (applied research). Penelitian terapan merupakan penelitian yang dilakukan untuk mendapat informasi guna memecahkan masalah secara praktis. Penelitian ini dilakukan sebagai respons terhadap suatu fenomena yang terjadi di lapangan. (Suliyanto, 2005). Penelitian dilakukaan untuk mengetahui alasan penetapan tarif ijarah yang berbeda dan pengaruhnya terhadap kepuasan (maslahah) nasabah.

Ditinjau dari jenis datanya, penelitian ini termasuk ke dalam penelitian kuantitatif, ialah penelitian yang berdasarkan pada kuantitatif dimana data kuantitatif adalah data yang berbnetuk angka atau bilangan. (Sugiyono, 2010).

\section{HASIL DAN PEMBAHASAN \\ 4.1 Hasil penelitian \\ Uji Hipotesis Dan Hasil Penelitian}

Kerangka pemikiran paradigm penelitian yang telah dibuat secara skematis, yang terdiri atas satu variabel independen dan satu variabel dependen, untuk mencari pengaruh variabel tertentu terhadap variabel lain. Dengan menggunakan statistik dengan menghitung besarnya koefisien determisi. Koefisien determisi dihitung dengan mengkuadratkan koefisien korelasi yang ditemukan, selanjutnya dikalikan dengan $100 \%$. Jadi judul penelitian ini, pengaruh besarnya tarif ijarah gadai syariah terhadap kepuasan (maslahah) gadai emas pertama-tama dihitung koefisien korelasinya.

Menentukan tingkat signifikan dan penarika sampel. Pengujian hipotesis akan dilakukan dengan menggunakan tingkat signifikasi sebesar 0,95 $(\mathrm{a}=0,05)$ karena tingkat signifikasi itu dinilai cukup memadai untuk mewakili perbedaan antara kedua variabel yang diuji. Dan merupakan tingkat signifikasi yang sering digunakan dalam penelitian ilmu sosial.

Penarikan kesimpulan dilakukan dengan membandingkan nilai $\mathrm{t}$ hitung dengan menggunakan nilai pada tabel distribusi $t$-student ( $\mathrm{t}$ tabel). Artinya kriteria penerimaan dan penolakan $\mathrm{H} 0$ sebagai berikut:

$H 0$ diterima dan $H 0$ ditolak bila : thitung $\leq t(1-\alpha)$ HO ditolak dan $\mathrm{HO}$ diterima bila : thitung $>(1-\alpha)$.

Untuk melihat signifikan atau tidaknya pengaruh tarif iajarah gadai syariah terhadap kepuasan (maslahah) gadai emas, maka perlu diadakan pengujian taraf signifikasi tersebut dengan uji statistik. 


\section{Jurnal Ilmiah Ekonomi Islam, 6(03), 2020, 612}

Bunyi hipotesisnya adalah tidak pengaruh yang positif dan signifikan antara tarif ijarah gadai syariah terhadap kepuasan (maslahah) nasabah gadai emas. Langkah dalam pengujian hubungan/pengaruh hipotesis secara simultan antara tarif ijarah gadai syariah terhadap kepuasan (maslahah) nasabah gadai emas, maka uji F. Hasilnya dapat dilihat berikut:

Tabel 1 Hasil Uji Regresi

Anova

\begin{tabular}{|l|r|r|r|l|l|}
\hline Model & $\begin{array}{r}\text { Sum of } \\
\text { Squares }\end{array}$ & df & $\begin{array}{r}\text { Mean } \\
\text { Square }\end{array}$ & F & Sig. \\
\hline 1 Regression & .027 & 1 & .027 & .003 & $.955^{a}$ \\
Residual & 314.373 & 38 & 8.273 & & \\
Total & 314.400 & 39 & & & \\
\hline
\end{tabular}

a. Predictors: (Constant), tarif ijarah

b. Dependent Variable: kepuasan nasbah

\section{Pengujian hipotesis:}

H0 : Tidak ada pengaruh tarif ijarah terhadap kepuasan (maslahah) nasabah gadai emas Bank Rakyat Indonesia syariah cabang Serang.

Kriteria pengujian hipotesis:

H0 diterima jika : F hitung $\leq \mathrm{F}$ tabel atau Sig $>0,05$

Hasil $\mathrm{F}$ dari pengaruh tarif ijarah gadaisyariah terhadap kepuasan (maslahah) nasabah diatas yaitu 003. Dapat disimpulkan bahwa H0 ditolak. Secara simultan tarif ijarah tidak berpengaruh atau tidak signifikan (lemah) terhadap kepuasan nasabah. karena nilai F hitung (003) atau Sig $(955) \leq$ alpha $(0,05)$, secara simultan tarif ijarah gadai syariah tidak berpengaruh yang positif (lemah) terhadap kepuasan (maslahah) nasabah.

Berdasarkan lampiran diatas menunjukkan bahwa persamaan jalur Tarif ijarah gadai syariah terhadap kepuasan (maslahah) gadai emas cenderung membentuk garis lurus, dengan menggunakan analisis jalur. Fungsi hubungan/pengaruh variabel bebas (Y) dan terikat $(\mathrm{X})$ diketahui, maka fungsi tersebut dapat memberikan dasar untuk perencanaan di waktu yang akan datang. Hasil pengolahan data adalah tabel berikut:

Tabel 2 Hasil pengolahan data

\begin{tabular}{|c|c|c|}
\hline Nilai F & Nilai F tabel & Kesimpulan \\
\hline .003 & 314.400 & $\begin{array}{c}\text { Tidak berpengaruh } \\
\text { (lemah) }\end{array}$ \\
\hline
\end{tabular}

Sumber : Hasil pengolahan data dengan program SPSS

Tidak ada pengaruh yang positif dan signifikan tarif ijarah terhadap kepuasan (maslahah) nasabah gadai emas.

Untuk mengetahui secara individu, harus dilakukan uji $\mathrm{t}$ terlebih dahulu, dengan mencari nilai $\mathrm{t}$ dari masing-masing variabel (Y), lalu dibandingkan dengan nilai $\mathrm{t}$ tabel, jika nilai $\mathrm{t}$ hitung lebih besar dari t tabel, maka hipotesis signifikan, artinya pengaruh yang terjadi dapat digeneralisasikan terhadap semua populasi. Sebaliknya, jika t hitung lebih kecil dari $\mathrm{t}$ tabel, maka hipotesisnya tidak signifikan, artinya pengaruh/hubungan yang terjadi tidak dapat digeneralisasikan terhadap seluruh populasi.

Tabel hasil perhitungan dan pengolahan data sebagai berikut:

Tabel 3 Hasil pengolahan data

\begin{tabular}{|c|c|c|}
\hline Nilai t & Nilai t tabel & Kesimpulan \\
\hline 3.510 & -.057 & $\begin{array}{c}\text { Tidak berpengaruh } \\
\text { (lemah) }\end{array}$ \\
\hline
\end{tabular}

Sumber: Hasil pengolahan data dengan program SPSS 16.0.

\section{Pengujian hipotesis:}

$\mathrm{H} 0$ diterima jika : $\mathrm{t}$ hitung $\leq \mathrm{t}$ tabel atau sig $>0,05$

\section{Karena:}

t hitung $\mathrm{Y}(-.057)>\mathrm{t}(\mathrm{n}-\mathrm{k})$ tabel atau sig $(.955)>$ 0,05

Secara parsial tarif ijarah pada gadai syariah tidak berpengaruh secara signifikan (lemah) terhadap kepuasan (maslahah) nasabah.

$\mathrm{R}$ square sebesar .000 perubahan kepuasan (maslahah) disebabkan oleh tarif ijarah pada gadai syariah tidak signifikan (lemah), sisanya ditentukan oleh variabel lain yang tidak diteliti.

\section{Pengaruh Tarif Ijarah Gadai Syariah Terhadap Kepuasan (Maslahah) Nasabah Gadai Emas BRISyariah Cabang Serang.}

Berdasarkan judul dan hasil penelitian melalui survei dan wawancara dengan pihak terkait, yang ada hubungannya dengan penulis, yaitu pihak BRISyariah cabang Serang, terutama dengan bagian gadai emas dengan nama Gadai Faedah, penulis dapat merumuskan dan menjelaskan hasil penelitian adalah sebagai berikut: 


\section{Jurnal Ilmiah Ekonomi Islam, 6(03), 2020, 613}

Pembuktian hipotesis konseptual secara statistik. Hipotesis yang diajukan penulis tidak ada pengaruh tarif ijarah terhadap kepuasan (maslahah) nasabah gadai emas. Dalam mengetahui nilai t hitung yang dihasilkan, penulis menggunakan analisis jalur, dalam proses perhitungan menggunakan SPSS 16.0 dengan hasil berikut:

Analisis yang digunakan dalam menganalisis data adalah analisis regresi linier sederhana, dalam prosesnya menggunakan SPSS.

Analisis regeresi digunakan untuk membangun persamaan dan menggunakan persamaan tersebut untuk membuat perkiraan, sering disebut analisis prediksi. Maka analisis prediksi tidak selalu tepat dengan nilai rilnya. Semakin kecil tingkat penyimpangan antara nilai prediksi dengan riilnya, semakin tepat persamaan regeresi yang kita bentuk. (Sugiyono, 2010). Dalam analisis ini, penulis akan memperoyeksikan meningkatnya kepuasan (maslahah) nasabah sebagai akibat adanya perubahan tarif ijarah yang ditetapkan. Disini ada satu variabel tergantung, yaitu kepuasan (maslahah) nasabah. Sedangkan variabel bebasnya ada satu, yaitu tarif ijarah. Permaslahan disini adalah adakah pengaruh tarif ijarah terhadap kepuasan (maslahah) nasabah pada gadai emas Bank Rakyat Indonesia Syariah cabang Serang secara simultan?

Dari analisis jalur diatas dapat diuraikan sebagai berikut:

Koefisien regeresi $\mathrm{Y}$ adalah 0,009 hal ini menunjukkan setiap peningkatan variabel tarif ijarah gadai syariah sebesar satu satuan nilai akan meningkatkan kepuasan (maslahah) gadai emas BRISyariah cabang Serang sekitar 0,009 satuan nilai dengan asumsi variabel lainnya kontstan.

Nilai eror 0,009 memperlihatkan besarnya pengaruh faktor lain diluar tarif ijarah terhadap kepuasan (maslahah) gadai emas sebesar 0,09\%. Dapat dipahami bahwa manajemen perlu memperhatikan variabel yang mempengaruhi kepuasan (maslahah) gadai emas, yaitu tarif ijarahnya, karena tidak mempengaruhi signifikan (lemah) karena diatas 0,5 .

Hasil pengolahan datanya dengan menggunakan SPSS dengan analisis regeresi sederhana adalah sebagai berikut:
Tabel 4 Hasil Uji Koefisien Determinasi Model Summary

\begin{tabular}{|l|c|r|r|r|}
\hline Model & $\mathrm{R}$ & $\begin{array}{c}\mathrm{R} \\
\text { Square }\end{array}$ & $\begin{array}{c}\text { Adjusted } \\
\text { R Square }\end{array}$ & $\begin{array}{c}\text { Std. Error of the } \\
\text { Estimate }\end{array}$ \\
\hline 1 & $.009^{\mathrm{a}}$ & .000 & -.026 & 2.876 \\
\hline
\end{tabular}

a. Predictors: (Constant), tarif ijarah

Dari hasil analisis dengan menggunakan korelasi, diperoleh nilai koefisien korelasi $(r)=0,009$. Artinya terdapat pengaruh yang tidak signifikan (lemah) antara tarif ijarah pada gadai syariah terhadap kepuasan (maslahah) nasabah.

Untuk nilai koefisien determinasi $\left(\mathrm{R}^{2}\right)$ diperoleh nilai $0,00 \%$ artinya variasi variabel kepuasan (maslahah) dapat diterangkan sebesar $0,00 \%$ oleh variabel tarif ijarah gadai syariah.

\subsection{Pembahasan Hasil Penelitian}

Dari hasil penelitian, bahwa gadai emas BRISyariah cabang Serang telah menurunkan tarif ijarahnya untuk menarik nasbahnya. Tetapi dalam mekanisme penetapan tarif ijarahnya masih menggunakan pegadaian konvensional, dengan mengakumulasikan dengan sejumlah uang pinjaman, dengan alasan untuk memudahkan pemahaman nasabah. Dengan demikian, perlu dijelaskan secara aturan gadai syariah kepada semua pihak, terutama kepada para nasabahny. Agar tidak ada persepsi atau anggapan dari masyarakat, bahwa gadai syariah tidak berbeda dengan pegadaian konvensional dalam penentuan tarifnya.

Oleh karena ada hal (implikasi) yang harus diperhatikan dari hasil penelitian ini:

1. Mekanisme penetapan tarif ijarah atau biaya sewa tempat penyimpanan dan pemeliharaan emas yang digadaikan perlu dijelaskan secara mudah dan rasional terhadap semua pihak yang berkepentingan, terutama terhadap para nasbahnya, agar tidak ada anggapan yang tidak baik, karena secara penglihatan dan pemikiran orang awan, bahwa gadai syariah dengan pegadaian konvensional tidak ada bedanya, dari mulai mekanisme penyerahan barang gadai, penaksiran, persyaratan, biaya administrasi, pinjaman, waktu lama pinjaman, hingga tarif ijarahnya (biaya sewa tempat). Sehingga bukan hanya mendapat profit yang diinginkan, tetapi bisa meningkatkan jumlah nasabahnya. Dari jumlah nasabah yang aktif perode tahun 2019- 


\section{Jurnal Ilmiah Ekonomi Islam, 6(03), 2020, 614}

2020 berdasarkan laporan dari pihak gadai emas BRISyariah, hanya ada 126 nasabah. Jika dihitung rata-rata dalam 1 tahun dalam perbulan, hanya ada 10,5 nasabah. Dengan demikian perlu ada promosi yang maksimal, baik melalui media sosial, media elektronik, dan media lainnya, agar nasabahnya meningkat, secara langsung meningkatkan profit bank itu sendiri.

2. Adapun pengaruh tarif ijarah gadai syariah terhadap kepuasan (maslahah) nasabah gadai emas BRISyariah cabang Serang tidak berpengaruh secara signifikan, karena diatas 0,05 , yaitu 0,955 . Maka semakin rendah atau murah tarif ijarahnya baik dari segi pembiayaan, administrasi, dan biaya sewa tidak ada pengaruhnya terhadap kepuasan nasabah.

Hal ini sesuai dengan hasil penelitian dan laporan keuangan tahun 2019 dan hasil angket berbentuk kuisioner terhadap nasbah gadai emas BRISyariah cabang Serang, sebagaimana yang terdapat dalam bab 4. Berdasarkan dari pihak gadai emas yang ada di bank tersebut, pada tahun 2019 - 2020 jumlah nasabah aktif kurang lebih 126 orang dan profit cenderung fluktuatif, cenderung pasif dari jumlah nasabah, dari hasil pembiayaan yang dikeluarkan gadai emas, keuntungan yang diperoleh $4,4 \%$ dalam satu tahun. Dimana profit tersebut, diperoleh dari biaya adminsitrasi dan tarif ijarah.

Selanjutnya penelitian ini mendukung teori alGahazali, bahwa pengurangan marjin keuntungan (profit) dengan mengurangi harga akan menyebabkan peningkatan kepuasan nasabah dan penjualan, dan karenanya terjadi peningkatan nasabah dan profit. (Adiwarman A Karim, 2006).

Dari diatas dapat dilihat bahwa pembiayaan gadai emas BRISyariah cabang Serang periode 20192020 sebesar Rp 10.403.915.000 profinya yang diperoleh dalam satu tahun Rp 462.070.950. Ketika dibagi perminggu dalam satu tahun menjadi 52 minggu, mengalami peningkatan fluktuatif dalam perminggu. Hal ini perlu penanganan tarif ijarahnya agar memperoleh profit yang diharapkan oleh pihak yang berkepentingan, baik karyawan, pemilik saham, dan orang-orang yang ada disekitar bank.

\section{KESIMPULAN}

Dari hasil uraian pada pembahasan sebelumnya tentang pengaruh tarif ijarah gadai syariah terhadap kepuasan (maslahah) gadai emas BRISyariah cabang Serang, maka selanjutnya dapat dirumuskan beberapa kesimpulan dan saran sebagai berikut:

Gadai emas BRI Syariah cabang Serang telah menerapkan pegadaian yang berdasarkan syariah, namun peningkatan nasabah dan profitnya belum optimal dan maksimal yang diharapkan. Dengan perhitungan analisis jalur dan regresi menggunakan program SPPS hasilnya sebagai berikut : Mekanisme penetapan tarif ijarah berdasarkan standar harga emas dipasaran dan fatwa Dewan Syariah Nasional (DSN) MUI. Pengaruh tarif ijarah terhadap kepuasan (maslahah) nasabah gadai emas BRISyariah cabang Serang menunjukkan tidak ada pengaruh yang signifikan, dimana tarif ijarah gadai syariah tidak diikuti peningkatan variabel kepuasan (maslahah), dengan intensitas lemah. Sebagaimana ditunjukkan hasil penelitian maka kepada pihak gadai emas BRISyariah cabang Serang dapat diajukan saran sebagai berikut : Gadai emas BRISyariah cabang Serang hendaknya memberikan informasi yang jelas dan transfaran tentang besarnya tarif ijarah atau biaya sewa dan biaya lainnya tentang gadai syariah, gadai emas BRISyariah cabang Serang dapat melakukan nalisis, perencanaan, pengendalian tarif ijarah, dan promosi yang inten terhadap masyarakat, agar tidak terjadi penurunan nasabah dan profit gadai emas. Apabila melakukan analisis dan promosi yang baik terhadap masyarakat, akan meningkatkan nasabah dan kepuasan nasabahnya, sehingga dapat meningkatkan profitnya. Gadai emas BRISyariah cabang Serang perlu menentukan tarif ijarahnya yang rasional dan obyektif terhadap para nasabahnya, sehingga akan memperoleh nilai kepuasan nasabah yang optimal.

\section{DAFTAR PUSTAKA}

Al-Qur'an (2003), Al-Qur'an dan Terjemahnya, Makah, Kerajaan Saudi Arabia.

Al-Syatibi (tt), al-Muawafaqat fi Ushul al-Syar'iah, Kairo, Musthafa Muhammad, jilid 2.

Ali Hasan M (2003), Berbagai macam Transaksi dalam Islam (Fiqh Muamalat), Jakarta, PT Raja Grafindo Persada.

Antonio Muhammad Syafi'i (2000), Bank Syariah dari Teori ke Praktek, kerjasama Gema Insani Press dengan Tazkia Institute, Jakarta, Gema Insani Press.

Arikunto Suharsini (2008), Prosedur Penelitian Suatu Pendekatan Praktik, Jakarta, Rieneka Cipta. 
Jurnal Ilmiah Ekonomi Islam, 6(03), 2020, 615

Askar S (2009), Kamus Arab - Indonesia al-Azhar, Jakarta, Sanayan Publishing.

Fatwa Dewan Syariah Nasional (DSN) No. 25/26/DSN-MUI/III/2002, Tentang Rahn dan Rahn Emas.

Ghofur Ruslan Abdul (2004), Pegadaian Syariah di Indonesia (Aplikasi Penerapan gadai Syariah pada ULGS Cabang Pemekasan dan Yogyakarta, Tesis, Pasca Sarjana Ekonomi Islam, UII Yogyakarta.

Jaziri Abdurahman (tt), Fiqh 'ala Madzahib alArba'ah, Jilid III, Beirut: Dar al-Fikr.

Karim A. Adiwarman (2007), Bank Islam: Analisis Fiqh dan Keuangan, Jakarta, PT Raja Grafindo Persada.

Kasmir (2010), Analisis Laporan Keuangan, Jakarta, PT Raja Grafindo Persada. Manajemen Perbankan, Jakarta, PT Raja Grafindo Persada.
Kuntowijoyo (1997), Identitas Politik Islam, Bandung, Mizan.

Naqvi Syeed Nwab Haider (2003), Menggagas Ekonomi Islam, Yogyakarta, Pustaka Pelajar.

Rais Sasli (2005), Pegadaian Syariah: Konsep dan Sistem Operasional, Jakarta, UI Pers.

Sugiyono (2008), Metode Penelitian Bisnis, Bandung, CV Alfabeta.

(2010), Metode Penelitian Kualitatif dan $R \& D$, Bandung, CV Alfabeta.

Suliyanto (2005), Metode Riset Bisnis, Yogyakarta, ANDI Yogyakarta.

Program SPSS 16.0.

Program SPSS 10.1 10Model Penelitian dan Pengolahannya.

Wahana Komputer (2002), Model Penelitian dan Pengolahannya dengan SPSSS 10.10, Yogyakarta, Andi Yogyakarta. 